\title{
Training a Day with English
}

\author{
Dini Safitri ${ }^{1}$, Chika Reza $A^{2}$, Tubagus Alfien $B^{3}$, Wenny Sabsela Marin ${ }^{4}$, Ira Anjani ${ }^{5}$, Nafila \\ Tri Hutami ${ }^{6}$ \\ Universitas Negeri Jakarta \\ dinisafitri@unj.ac.id ${ }^{1}$
}

\begin{abstract}
Education is an activity that is common to every human being on this earth. Education cannot be separated from all forms of human activities. The teaching and learning process is certainly a core activity in the whole process of education in school or formal education. English is a language that is commonly used in several countries, therefore knowledge and learning of English are very important for the development of children's knowledge. Introduction, and learning things in the child's environment can initiate children's interest in learning English. This activity aims to provide knowledge to children about the use of English in everyday life when children communicate in English, children become easier to know the meaning of words and their meanings because the material is learned based on the science of direct practice. Because the concentration of children at an early age is still very minimal and uncontrollable, the most appropriate method is by learning and playing where children can understand the material well because of the learning and teaching process that attracts children's interest. With this method, the interest of children is no longer only interested in how to play or just give rewards, but children will be happy with the repetition of the things he had learned before. So, children's interest in learning will increase concerning things he already knows.
\end{abstract}

Keywords: Education, Interest, Learning, and Playing.

\section{INTRODUCTION}

Education is an activity that is common to every human being on this earth. Education cannot be separated from all human activities. Under no circumstances can humans reject the effects of the application of education. The teaching and learning process is certainly a core activity in the whole process of education at school. But in reality not all students can achieve the expected results, namely understanding the material well because of the use of inappropriate methods.

English is a foreign language that becomes the universal language of every country, understanding English is a must as the main or general language of each country. The importance of knowledge of English is to familiarize children with the use of the language itself, by introducing English, let alone communicating with English, adding insight to children is not only about the meaning of words but the meaning of using words in a situation.

PKM activities or (Community Service) is an activity that aims to help certain communities in several activities without expecting any kind of reward. In general, this program was designed by various universities or institutes in Indonesia to make a real contribution to the Indonesian nation, especially in developing the welfare and progress of the Indonesian people. Community Service Activities is one part of the Tri Dharma of Higher Education. The PKM activity we will do is teach English in the Desa Pendidikan in the Pulo Gadung area. Education is a long-term investment that requires considerable effort, this is acknowledged by all nations, especially Indonesia, which has great hopes for the generation of educators for the future survival of their nation. With that we want to do teaching activities and also educate children in the Desa

September 2019 
Pendidikan, and we want to teach the basics of learning English such as, how to start conversations, and vocabulary that is easily learned by students of Desa Pendidikan with the aim of knowledge that we have we can share and be useful.

Based on the information of Rachmat Suryadiansyah as the Head of the Desa Pendidikan School, for teaching core subjects such as mathematics, Indonesian, and also science already fulfilled by teacher teachers from the Desa Pendidikan themselves, but to focus on learning English it seems that it cannot be fulfilled due to lack of human resources or instructors who master the language. For that, we chose A day with English as our PKM program, which is one day dedicated to understanding and also learning English.

Through learning and playing techniques, it is hoped that it can be used as a starting point for increasing the creativity and mastery of English-language material, by learning while playing students remember and understand easily. Learning while playing is used as a way to create learning activities in a fun process.

Desa Pendidikan is a teaching program run by BEM FIS UNJ (Student Executive Board of the Faculty of Social Sciences, Jakarta State University) and Red Solider Action Team, where students can conduct community service in the form of education/teaching, entrepreneurship training, health guidance, and youth empowerment. Located at Jalan Kayu Putih RW.003, Rawamangun. Desa Pendidikan itself was previously one of the work programs of the BEM Faculty of Social Sciences. However, this project is a very good activity and is still maintained until now. Also, Desa Pendidikan is an activity in the social realm 3 of the Faculty of Social Sciences BEM for community service activities in a social form.

Humans in their nature as social beings always want to connect with other humans, want to know the environment, even want to know what is happening in him. This curiosity forces humans to communicate. In addition, it is also given in the form of thoughts that develop and can be developed. Humans always live together with other humans. The encouragement of people who are nurtured from birth will always reveal themselves in various forms. because that by itself humans will always be social in their lives.

According to Harold D. Lasswell (2009: 6), a foundation developer of communication science says there are three basic functions why humans need to communicate, namely human desire to control their environment, human efforts to adapt to the environment, and human efforts to transform heritage and socialization.

Conveying Mind and Feelings As Effendi (2011: 70) said in his book, that one of the functions of communication is emotional disclosure. By communicating we are facilitated to be able to express what we think and feel. Expressing personal thoughts and feelings to others is important to do. Because by expressing the contents of thoughts and emotions whether angry, happy, disappointed, happy, or other emotions; other people understand what we feel. On the other hand, we will get a life balance and spaciousness of heart.

Giving Information According to Effendi (2011: 71) Information is quite important, information can prevent us from making mistakes. For example, providing information about the direction of a place can prevent someone from straying to the place. Or information about how to use a tool, it is important to know so that no product failure can affect the damage to the device.

Adding Insight / Knowledge Menurtu Effendi (2011: 72) one of the functions of communication is to educate. Human communication can convey knowledge, ideas, or ideas and allow the transfer of knowledge from someone to someone else. That way someone's insight and knowledge about a thing will increase. 


\section{METHOD}

The method used in this activity is learning and playing. Playing is an activity or activity to please both using certain tools or not using certain tools without thinking of the final results. While learning has the meaning of a process of change that occurs in a person from not understanding to understanding.

Every early childhood, in general, would love to play, because the world of children is a world of the play, not the world of learning. Therefore, an educator should, when he wants to provide learning for early childhood, be managed by playing.

This is so that children are interested in learning if managed by playing, for example when we want to teach counting to early childhood, a game must be made that can attract attention to learning. Therefore, all activities carried out by early childhood are essentially done by playing.

Playing while learning by learning while playing, of course, has different meanings. The difference is, if playing while learning has meaning in the process of playing children will get learning. But instead learning while playing has meaning in a learning process children will get a game. In early childhood, playing activities for them are important activities.

This is because their time is the time to play, even though they are led to start learning activities, but children are not too forced to learn. in early childhood, they learn to be faster and more effective when done when they play. So playing is one of the basic needs of children as a form of learning for them.

This is because playing that is carried out in learning activities will not only be liked by children but also very beneficial for children's development and besides playing with them, the energy that children have that is excessive will be channeled well. So that later the child will get a lot of valuable experience through playing, which will later be useful for children to face the life to come.

In general, the process of education in early childhood takes precedence over the method of playing while learning. This is done because this method is more in line with the conditions of children who tend to prefer playing. So educators use this to educate them by playing while learning, besides playing them while honing their skills and abilities. This method will be more memorable in the memory of children's brains for the development of their knowledge because at an early age is a very rapid development of brain memory.

Around the world, children play. Playing for children is like working for an adult human. Some children play properly, but some play "quite dangerous" they do as children. The role of education is to guard how the game can develop them properly and intact as human children.

Activities carried out more as play activities so that they later indirectly develop good attitudes as well as for logic and ethics or manners. Play and learning activities must make them actively use the members of the body, move them so that physical and mental development can take place in balance according to their potential.

Children always grow and develop. They display different physical and psychological characteristics for each stage of their development. Childhood is the peak of their creativity, and their creativity needs to be maintained and developed by creating an environment that values creativity through play. Therefore, education at an early age that emphasizes playing while learning can encourage children to spend all their creativity.

\section{RESULTS}

This A Day with English activity went very well following the arrangement of activities that had been made and targeted according to the first-grade students of SD in the Desa Pendidikan. This activity takes place on Saturday, 4 May 2019 from 10:00 to 12:00 in Pulo Gadung Educational Village. However, there are differences from the provision of material that 
has been planned, namely by using a projector. When the activity took place the provision of the material was not done by using a projector due to inadequate situations in the absence of a barrier between each class which was feared that the use of projectors would disrupt teaching and learning activities in other classes. Besides, not using the projector was also not done because there were less than 10 students in grade 1 elementary school, where the delivery of material only orally to less than 10 students was quite effective. Finally, the solution we chose was to continue to hold teaching and learning activities by making small circles specifically for children in grade 1.

Table 1. Target activities according to the method cited

\begin{tabular}{clrl}
\hline No. & \multicolumn{1}{c}{ Method } & \multicolumn{1}{c}{ Target } \\
\hline 1. & Learning & while & $50 \%$ of students can sing happy English songs given without being \\
& $\begin{array}{l}\text { singing } \\
\text { Learning } \\
\text { playing }\end{array}$ & while & $\begin{array}{l}\text { guided. } \\
50 \% \text { of students can submit pictures given using English }\end{array}$ \\
\hline
\end{tabular}

The Community Service activities in the Desa Pendidikan are already quite good because considering the time the activities took place following the plans made, apart from some of the shortcomings the committee can continue to carry out the activities well. Submission of material is quite good because during the games activities and giving quiz questions based on the material taught almost more than $50 \%$ of students - students can answer it well and enthusiastically. This is of course following the target of the activity.

\section{CONCLUSIONS}

PKM learning activities while playing in the Desa Pendidikan in this way is very interesting interest in learning children. By introducing this new method by providing stimuli in the form of quizzes, as well as prizes where later competitive attitudes to children's learning increase. Children tend to like learning repetition, which makes them interested in knowing what they have learned before. With the selection of activities that match the abilities or interests of children, they will train themselves in decision making. This activity made the Desa Pendidikan students feel so happy.

\section{REFERENCES}

Books

Khairani, Ade Irma. (2016). Pendidikan Bahasa Inggris untuk Usia Dini. Medan: Politeknik Negeri Medan

Drs. Tommy Suprapto. M.S, ed. 2009. Pengantar Teori dan Manajemen Komunikasi, Jakarta: Media Pressindo

Others

Harold D. Lasswell, ed. 2009. Structure an Function of Communication in Society

Hasfy B. $2018 . \quad$ Belajar $\quad$ Sambil Bermain. (https://www.kompasiana.com/hafsy/5bf655d8c112fe11875a13b8/bel ajar-sambil-bermain) Diakses pada 7 April 2019 pukul 10.30 Ivony. 2017.

Fungsi-fungsi Komunikasi. (https://pakarkomunikasi.com/fungsi-fungsi-komunikasi) Diakses pada 1 April 2019 pukul 13.54

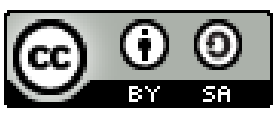

(C) 2019 by the authors. Submitted for possible open access publication under the terms and conditions of the Creative Commons Attribution (CC BY SA) license (https://creativecommons.org/licenses/by-sa/3.0/). 